\title{
Correction to: Are the Global Strategic Directions for Strengthening Nursing and Midwifery 2016-2020 being implemented in countries? Findings from a cross- sectional analysis
}

Onyema Ajuebor ${ }^{1 *}$, Carey McCarthy ${ }^{1}$, Yin Li ${ }^{2}$, Sumaya Mohamed Al-Blooshi ${ }^{3}$, Nonhlanhla Makhanya ${ }^{4}$ and Giorgio Cometto ${ }^{1}$

Correction to: Hum Resour Health (2019) 17:54

https://doi.org/10.1186/s12960-019-0392-2

Following publication of the original article [1], the authors identified an error in Table 2. The correct table is given below.

\section{Author details \\ ${ }^{1}$ Health Workforce Department, World Health Organization, 20 Avenue Appia, CH-1211 Geneva 27, Switzerland. ${ }^{2}$ Nell Hodgson Woodruff School of Nursing, Emory University, Atlanta, USA. ${ }^{3}$ Nursing Department, Ministry of Health and Prevention, Abu Dhabi, UAE. ${ }^{4}$ National Department of Health, Pretoria, South Africa.}

Published online: 17 July 2020

\section{Reference}

1. Ajuebor O, et al. Are the Global Strategic Directions for Strengthening

Nursing and Midwifery 2016-2020 being implemented in countries?

Findings from a cross-sectional analysis. Hum Resour Health. 2019;17:54

https://doi.org/10.1186/s12960-019-0392-2.

The original article can be found online at https://doi.org/10.1186/s12960019-0392-2.

* Correspondence: ajueboro@who.int

${ }^{1}$ Health Workforce Department, World Health Organization, 20 Avenue Appia, $\mathrm{CH}-1211$ Geneva 27, Switzerland

Full list of author information is available at the end of the article

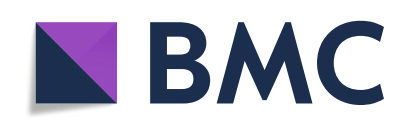

(- The Author(s). 2020 Open Access This article is licensed under a Creative Commons Attribution 4.0 International License, which permits use, sharing, adaptation, distribution and reproduction in any medium or format, as long as you give appropriate credit to the original author(s) and the source, provide a link to the Creative Commons licence, and indicate if changes were made. The images or other third party material in this article are included in the article's Creative Commons licence, unless indicated otherwise in a credit line to the material. If material is not included in the article's Creative Commons licence and your intended use is not permitted by statutory regulation or exceeds the permitted use, you will need to obtain permission directly from the copyright holder. To view a copy of this licence, visit http://creativecommons.org/licenses/by/4.0/. The Creative Commons Public Domain Dedication waiver (http://creativecommons.org/publicdomain/zero/1.0/) applies to the data made available in this article, unless otherwise stated in a credit line to the data. 
Table 2 Percent of interventions reported as "not started", "in progress" and "completed" by thematic area

\begin{tabular}{|c|c|c|c|c|c|c|}
\hline Thematic Area & $\begin{array}{l}\text { No. of } \\
\text { interventions }\end{array}$ & $\begin{array}{l}\text { No. of } \\
\text { responders }\end{array}$ & $\begin{array}{l}\text { Not started } \\
\text { N (\%) }\end{array}$ & $\begin{array}{l}\text { In progress } \\
\mathrm{N}(\%)\end{array}$ & $\begin{array}{l}\text { Completed } \\
\text { N (\%) }\end{array}$ & $\begin{array}{l}\text { In progress \& } \\
\text { completed N (\%) }\end{array}$ \\
\hline $\begin{array}{l}\text { 1. Ensuring an educated, competent and motivated nursing } \\
\text { and midwifery workforce within effective and responsive } \\
\text { health systems at all levels and settings }\end{array}$ & 7 & 35 & $61(25 \%)$ & $123(50 \%)$ & $61(25 \%)$ & $184(75 \%)$ \\
\hline $\begin{array}{l}\text { 2. Optimizing policy development, effective leadership, } \\
\text { management and governance }\end{array}$ & 6 & 35 & $42(20 \%)$ & $122(58 \%)$ & $46(22 \%)$ & $168(80 \%)$ \\
\hline $\begin{array}{l}\text { 3. Working together to maximize the capacities and } \\
\text { potentials of nurses and midwives through intra- and } \\
\text { interprofessional collaborative partnerships, education } \\
\text { and CPD }\end{array}$ & 4 & 35 & $46(33 \%)$ & 77 (59\%) & $10(8 \%)$ & $87(67 \%)$ \\
\hline $\begin{array}{l}\text { 4. Mobilizing political will to invest in building effective } \\
\text { evidence-based nursing and midwifery workforce development }\end{array}$ & 5 & 35 & $53(30 \%)$ & $93(53 \%)$ & $30(17 \%)$ & $123(70 \%)$ \\
\hline Overall from four thematic areas & 22 & 35 & $200(26 \%)$ & $420(55 \%)$ & $150(19 \%)$ & 570 (74\%) \\
\hline
\end{tabular}

